\title{
GOVERNING BY LOOKING BACK: HISTORICAL ANALOGIES AND CRISIS MANAGEMENT
}

\author{
ANNIKA BRÄNDSTRÖM, FREDRIK BYNANDER AND PAUL 't HART
}

This article offers a conceptual framework that broadens and enhances our understanding of the role of 'history' in contemporary governance and the attempts by policy-makers to 'manage' critical issues. Building upon the literature on historical analogies in policy-making, we distinguish three dimensions that clarify how the past may emerge in and affect the current deliberations, choices and rhetoric of policy-makers. We apply this in a comparative examination of two cases of crisis management where historical analogies played an important part: the Swedish response to (alleged) submarine intrusions in 1982, and the European Union sanctions against Austria in 1999. We induce from the case comparison new concepts and hypotheses for understanding the role of historical analogies in public policy-making and crisis management.

\section{INTRODUCTION}

A common misunderstanding about crises - understood here as epochs of profound uncertainty and urgent challenges to the problem-solving capacities of the socio-political order in which they occur - is that they are all unique. Of course at one level this is true. Each disaster has its own physical characteristics, each escalated conflict its own history, each corporate breakdown its own scenario. Yet if one goes beyond the specifics of time, place, method and scale, or if one looks not at the physical events but at the challenges to communities and policy-makers these events entail, crises lose their sense of uniqueness.

Moreover, crises are linked through time. When faced with the uncertainty and confusion that marks a crisis, people will search their memories and their knowledge base for situations that can at least give some clue as to what is going on. Policy-makers and organizations dealing with crisis draw upon some of these past experiences, however 'unique' the current predicament may seem, to find clues about what to do and what to avoid. In that sense, they govern by looking back.

The use of memory in governance and crisis management may happen in different ways and serve various purposes. Most scholars focus on two aspects. One concerns learning in crises - the use of historical analogies during crisis decision-making (May 1973; Hybel 1990; Breslauer and Tetlock 1991; Khong 1992; Bennett 1999; Houghton 2001). ‘Cognitive' interpretations

Annika Brändström and Fredrik Bynander are at the Swedish National Defence College, Stockholm. Paul 't Hart is at the Utrecht School of Governance, Utrecht. 
tell us that policy-makers draw upon the past to grasp their situations and discover and weigh their policy options. Policy-makers thus try to learn from the past, even if they do so badly (Neustadt and May 1986). 'Political' explanations hold that policy-makers use the past opportunistically, that is, to mobilize support for choices they have already made on other grounds (cf. March and Olsen 1975; Levitt and March 1988). Policy-makers invoke history to sell policies rather than to discover them.

The other issue discussed in the literature deals with learning from crises the extent to which crises provide opportunities for policy-oriented learning (Sabatier and Jenkins-Smith 1993; Levy 1994; Stern 1997). Optimists portray crises as learning opportunities. Crises profoundly shake those who experience them first hand, and send warning signals to people and organizations in similar settings. In this view, crises have a self-denying propensity: their very unacceptability motivates actors to prevent their recurrence (Mannarelli, Roberts and Bea 1996). Ideally, organizations in high-risk environments learn from incidents and crises to develop a self-monitoring, resilient 'safety culture' (Pidgeon 1997). Crises can have a catalytic effect, making people concentrate their attention and redefine the issues at hand (Blight 1990; Stern 1997). Pessimists are less sanguine about policy-makers' ability, and indeed their willingness, to critically evaluate their past performance during such intensely political episodes (Staw, Sandelands and Dutton 1981; Etheredge 1985; Sagan 1993). They will be motivated to exaggerate their successes, and thus 'over-learn' from them into the future (Rosenthal and 't Hart 1989), and to obfuscate or explain away their failures, and thus 'under-learn' from them (Bovens and 't Hart 1996; cf. Hacker 2001).

In this article we seek to develop a conceptual framework that extends existing approaches. It aims to provide a richer, subtler picture of the links between the past and present in crisis management practices. We first present a concise conceptual framework. We use this to present two explorative case studies of governmental crisis management where historical analogies were important yet problematic influences on policy-makers. It should be noted here that the two cases were selected purely for illustrative purposes: we knew from prior research that they provided rich evidence of decision-makers drawing on history in managing a current crisis. The comparison is mainly with a view to theoretical exploration, not empirical generalization. The cases are reported and accounted for more fully in: Bynander (1998a, b, 2002, 2003) and S. Larsson and Lundgren (2001, 2003). We subsequently compare the case findings to induce additional concepts and hypotheses about the roles of historical analogies in public policy-making.

\section{COPING WITH CRISIS BY SEARCHING THE PAST}

Crises conjure up memories and invite historical comparisons. Because of the high stakes and pressures involved, they are times that will be remembered (Caruth 1995). Crises are also characterized by pervasive uncertainty about what is going on and what is still to come. Often gaps in the knowl- 
edge and understanding that policy-makers and other crisis actors require in order to know what to do cannot be filled quickly enough by conventional intelligence gathering and expert advice. Policy-makers therefore use shortcuts in getting a grip on what is happening. Among these shortcuts are a resort to personal experience, educated guesses by key associates and advisers, readily available precedents embedded in institutional memory and official contingency planning (standard operating procedures - SOPs), and storylines developed in mass media accounts of the events. All of these mechanisms make reference to the past, whether the personal or the shared, the recent or the distant, the community's own or some other people's past.

The past here refers to the gamut of events that have occurred before the 'now' in which crisis actors find themselves. Understood in this way, the past is like a giant database. Parts of the past settle in memory, which we define as individual and collective recollections of the past. Memory needs to be distinguished from the notion of history, which we use to denote particular versions of the recorded past, that is, segments from the remembered past that have been melted into an authoritative story about the past (Butler 1989; Foote 1990). Moving cognitively from past to memory to history involves processes of reduction and interpretation, both semi-spontaneous and organized ones. As a consequence, only parts of the past are remembered and memory may be at odds with history (Smith 2001). For some parts of the past, a dominant storyline emerges and evolves over time. Others remain unsettled, continuously subject to historical revisions and controversies (Schudson 1992) or are 'forgotten' by history-makers (that is, power-holders, professional historians, journalists, film makers; see also Middleton and Edwards 1990; Sturken 1997).

Most of the policy-making literature ignores the distinction between the past, memory and history, and threatens to overlook the important differences between them. Yet if we want to know if and how the past influences actors in a crisis we should look more carefully and ask which past, whose memories and what histories are involved. In our view an historical analogy is applied when a person or group draws upon parts of their personal and/ or collective memories, and/or parts of 'history', to deal with current situations and problems (cf. May 1973; Khong 1992). The best known among these are the so-called 'big' analogies or 'master frames' (Snow and Benford 1992): standardized evocations of global, epoch-making charismatic figures and critical episodes (for example, 'Munich').

When tracing the retrieval and cognitive or political influence of an analogy, certain criteria must be set for analytical use. Whether 'used' as a political vehicle, or retrieved as a form of cognitive schema, the manifestation may be similar, and the possible modes of utilizing the past difficult to discriminate between. However, as Khong points out (1992, pp. 59-60) the comparison between private and public use (private referring to statements not intended for public consumption) can be used to shed light on this analytical dilemma. Detecting the use of a certain analogy in public can validate 
its significance to the political process at hand, thus showing that the analogy is 'active' on some level. The use of the same analogy in internal deliberations, diaries, or in personal reflections can, barring the limitations stipulated by source criticism, add evidence of the cognitive dimension. The combination of the two types of sources allows the researcher to compare the evidence of retrieval with the tasks that analogies hypothetically perform once active. By counterfactual reasoning (Tetlock and Lebow 2001, 831ff.), the fit between those tasks and policy behaviour prescribed by the analogy can be assessed and provide evidence not only regarding whether an analogy is active, but also whether it exercises influence beyond public advocacy of a general policy option (Khong 1992; see also Shimko 1995, p. 73; Hemmer 1999, 268ff.).

There is, however, something misleading in saying that policy-makers 'use' historical analogies. This suggests that doing so is a conscious, willful act. This can be but need not be the case (Butler 1989; Connerton 1989; Caruth 1995). We surmise that there are three key questions that need to be addressed when we want to understand the role of the past in crisis management, particularly the role of historical analogies. First, how do policy-makers remember the past, that is, how do they organize memory (Covington 1985) and 'make' history? A vital distinction to be made here is between intentional and spontaneous modes. In the intentional mode, policy-makers take explicit initiatives to search for and apply relevant experiences. They try to 'shape' the use of the past. In the spontaneous mode, the past is more likely to encroach on policy-makers. It is more likely to come in the form of their personal experiences or interpretations of history, or as a result of ad-hoc communications to them from people in their networks. Sometimes, it is a matter of books they happen to read, or the examples set by early career mentors (see Isaacson and Evan 1986, pp. 180-8, 391). Such spontaneous modes of retention are likely to be more unpredictable and less robust over time than deliberate and institutionalized ones (such as legal precedents or SOPs).

Secondly, when they do draw upon memory and history during a crisis, how and why do policy-makers do so? This is where the difference that was made earlier between cognitive and political modes of utilizing the past comes in. Some policy-makers will, in a crisis, use memory and history to make sense of the confusing events in which they find themselves. According to Khong, for example, policy-makers use analogies to perform various 'diagnostic tasks', such as helping to define the situation, assess the stakes involved, and predict the chances of success of various policy options (Khong 1992, pp. 7-10; cf. Houghton 2001). This closely resembles what proponents of the so-called naturalistic decision-making model describe as 'pattern recognition' (Flin 1996). However, policy-makers may also draw on images of the past not so much to enhance their own understanding of the crisis as to tell others what it is all about. Such 'political' use of memory and history is helpful, at least to the policy-makers, when it assists them in convincing 
actors and accountability fora whose support is essential, that their preferred policy option is (or was) effective and proper under the circumstances. It fails when the use of a particular representation of the past is widely challenged as being fallacious or manipulative.

Thirdly, what do these types of uses of the past 'do' to policy-makers and to the overall course of the crisis? Here one should distinguish between the 'enabling' and 'constraining' impacts of the past (cf. 'path dependency', Pierson 2001). The terms enabling and constraining are used here in a valueneutral way. Hence the past constrains when it narrows the definition of the crisis and the range of options policy-makers consider relevant in dealing with it; it enables when it broadens the cognitive and action repertoires of policy-makers. (Even retrospectively, it is often hard to assess the relative degree to which analogies to the past influence the behaviour of policymakers, who have to take into consideration so many other factors when making and justifying their choices (see Houghton 2001). In this exploratory paper we assume that if we can find evidence of uses of the past in a particular case of crisis, such uses have also had a non-negligible impact upon the overall policy-making process. In future studies, this assumption would have to be tested critically.) Figure 1 brings the three questions together, and models the range of possible answers to them as three conceptually distinct continuums that can be used to 'place' the observed uses of the past by any policy-maker or group at any stage of any given case of crisis management. Taken together, they depict the mental-historical space within which actors can move when they deal with a crisis.

We shall illustrate and discuss each dimension of the historical space of crisis management drawing upon two case studies. They were selected chiefly on the basis of their illustrative value; we do not claim they are representative for all crises, nor do we claim they exhaust the range of possible modes of remembrance and utilization of the past by public policy-makers. The cases are drawn from two much larger 'case banks' compiled by the two research groups the authors are members of. The case studies encompass detailed chronological reconstructions of the main events and

I: MECHANISM 1: Modes of remembering the past

Intentional $======================\quad$ Spontaneous

II: MECHANISM 2: Modes of utilizing the past

Cognitive======================== Political

III: IMPACT: Effects on policy process and outcomes

Constraining $======================$ Enabling

FIGURE 1 The historical space of crisis management 
decision-making sequences, as well as thematic analyses of specified aspects of crisis decision-making. They are based on a combination of policy documents, media coverage, interviews with policy-makers, and in some cases intensive 'witness symposiums' where key stakeholders are invited to share and compare their personal recollections in a group setting (see Stern and Sundelius 2002). A caveat is also in order here. In this article we only demonstrate how policy-makers reach back from one crisis to a past, morphologically similar crisis, to deal with a current one. In reality, policy-makers might draw on a range of different, that is, non crisis-like, parts of the historical space to inform or explain their behaviour when dealing with crises.

\section{'EVIL IS LURKING': SANCTIONS AGAINST AUSTRIA}

\section{The crisis: challenge, response and outcome}

Following its success in the October 1999 parliamentary elections, the Freiheitliches Partei Österreich (FPÖ) was invited for coalition talks by the prospective Christian-democratic Chancellor. Led by the controversial Jörg Haider, the FPÖ was widely seen as a party of the extreme right. Haider's tough rhetoric on foreigners and immigration as well as his close ties to Austrian Nazi war veterans had already led the FPÖ to be banned from the association of liberal parties in Europe. The risk of such a party coming to national political power in a EU member state was perceived by many as an appalling prospect. It would call into question the democratic authenticity of the Union, at the very time when the EU was imposing stringent norms of democracy and respect for human rights in evaluating the membership applications of former Eastern bloc countries. In short, electoral developments in one member state were perceived by the others as a threat to the regional institution as a whole.

There was also a high degree of time pressure. The first to take action within the group of European leaders was the Belgian Prime Minister, Verhofstadt. In a fax he suggested that the President of the European Council (Portuguese Prime Minister Guterres) organize a joint statement of the other member states. Guterres forwarded the fax to all the other leaders, along with a question: what do we do? A small group of government leaders then drew up a proposal to threaten with sanctions and sent it around to the others.

The leaders of the 14 other member states (hereafter: the 14) decided to threaten Austria with political sanctions if the FPÖ were to participate in the new government. The action against Austria was motivated by their shared expectation that an Austrian government with the FPÖ in it was going to disregard Article 6.1 of the Amsterdam Treaty containing the founding principles of the EU (freedom, democracy, rule of law, respect for human rights and basic human privileges). Since the Treaty does not support actions against member states until violations of these principles actually occur, which had not been the case in Austria at the time, the sanctions were formally to be a parallel set of bilateral sanctions of each member state against Austria. 
Political consensus among the 14 to press ahead with the policy of deterrence was engineered over the course of a single, hectic weekend, and the final decision to go ahead with the plan was taken on Sunday 30 January. Some country leaders were given very little time to respond. Moreover, it was made clear by the main proponents of the plan (the Portuguese Presidency and the Belgian Government in particular) that 'yes' to the sanctions was really the only proper course of action. Evidently none of the 14 wanted to go against these claims, or risk getting depicted as being 'soft' on Haider: consensus emerged very quickly, as compared to other occasions of EU crisis management.

The sanctions threat failed to prevent FPÖ's participation in the new Austrian Government. In February 2000, a coalition between the Christian Democrats and FPÖ came to power. In response, the 14 effected their threat: Austria was ostracized from diplomatic and EU arenas. Seven months later, however, the sanctions were lifted after a report by three 'wise men' that had judged that the FPÖ and the new government were behaving responsibly and democratically.

\section{Analogical reasoning in the sanctions case}

To a large extent, the conviction that Haider and the FPÖ had to be kept out of government and thus be prevented from entering the European governance network was inspired by one recurrent historical reference: Haider was constantly being compared with Adolf Hitler, and the FPÖ with the National Socialist party. Reportedly, the main reason why the European political reaction was so strong was that many had become convinced that Haider was 'following in the footsteps' of Hitler, thus projecting a troublesome future from the analogy with a catastrophic past (Hrbek 2003).

At the Holocaust conference in Stockholm in January 2000, Haider and the developments in Austria were mentioned on several occasions. Israeli Prime Minister Barak said that 'for every Jew in the world it is a highly disturbing signal... it touches everyone of us' (quoted in the Guardian Jan 27, 2000). Shimon Peres observed that as had Hitler, Haider was coming to power through democratic means. Letting Haider into the government would be a disastrous mistake (Hammargren 2000). A week later the Swedish foreign minister, the late Anna Lindh, stated, 'one week after the speeches at the Holocaust remembrance ceremony it is even harder to accept a xenophobic government in Europe again' (TT 2000). German Chancellor Schröder said that he had listened carefully to Israeli Prime Minister Barak's speech at the conference, and that this had persuaded him to push even harder for farreaching sanctions against Austria. At other occasions, Barak and Peres, when asked about Haider, mentioned that Austria was also Hitler's birthplace: 'Hitler was from Austria and any man who causes so many doubts must also raise the alarm everywhere' (Peres quoted in the Guardian, 27 January 2000). Overall, the coincidence of the Holocaust conference and the FPÖ's possible participation in the Austrian coalition appears to have been 
an important factor in framing the latter in particular historical terms. It most likely boosted both the availability and the perceived salience of the Hitler analogy (see Houghton 2001). The motivation to espouse these actions towards Austria was perhaps boosted by the domestic experiences of extreme right-wing parties of some of the European states. But this was not true for all the members of the 14, for instance Portugal with a crucial role in organizing the sanctions. Remarkably, neither before nor after the Austrian case have major political advances of right-wing populist parties (such as Berlusconi's rise to power in Italy in a coalition with neo-fascists; major local and regional election victories for the Front National in France and the Flemish Bloc party in Belgium) been defined as political crises and met with such a strong response (Berger 2001).

\section{MECHANISM 1: mode of remembrance: spontaneous and evoked analogies}

In the case of the sanctions the past was remembered in a spontaneous rather than deliberate way. As far as we can establish, the personal memories and inferences of the leaders dominated the deliberation process, with little room for systematic staff work. No formal situation reports or evaluations of past uses of the sanctions instrument or plans were produced or utilized. A limited number of EU leaders with strong personal beliefs, rooted in forceful images of the past, pushed the policy forward. The others went along, with varying degrees of conviction. Authoritative outsiders such as Barak and Peres may have acted as moral entrepreneurs. The coincidental occasion of the Holocaust conference served as a backdrop to emphasize the gravity of the worst-case scenario (that is, a political situation in Austria where Haider would lead Austria towards an undemocratic and xenophobic future).

\section{MECHANISM 2: mode of utilization: cognitive and political framing}

In the sanctions case, cognitive and political uses of the past were closely intertwined. In diagnostic terms, the prevalence of the Hitler analogy made it clear that there was a serious threat to Europe. This threat needed to be curtailed before it grew any stronger. Politically, the analogy lay at the heart of the pressure the supporters of the sanctions policy brought upon the less committed leaders to tow the line. Any lingering doubts from the other leaders were neutralized.

Clearly it was neither the cognitive nor political power of the analogy alone that clinched the 14 's unanimity on the sanctions. The decision-making process was to some extent manipulated. When the other leaders were asked one by one to respond to the core group's proposal, they had to make their decision immediately. Moreover, they were all given the impression that the other states had already given their agreement, a classic manipulation ploy.

In the sanctions case, the Hitler analogy certainly influenced the way in which European leaders performed their 'diagnostic tasks'. It made them 
frame the issue as the overtly democratic rise to power of a fascist; it gave them a conviction that the stakes of stopping him were high; it told them that there was no room for hesitation or weakness in tackling the problem; and it provided them with a moral underpinning for an unprecedented and legally questionable course of action.

What the Hitler analogy did not, and could not, do, however, was to give the European leaders an even-handed prediction of the likelihood of success of their preferred policy option. Since Hitler had never been met by firmness until the war broke out, the European leaders (sanctions are more effective than 'complacence' or 'appeasement') made a counterfactual inference. As it turned out, the sanctions were ineffective. They did not deter the Austrians, particularly the Christian-democratic leader Schüssel, from creating a coalition that included the FPÖ (albeit without Haider in a ministerial position).

This outcome may have been less surprising if the European leaders had looked at other parts of the past. In general, the record of sanctions as an instrument of international diplomacy is uneven at best (Baldwin 1985; Martin 1992). Specifically in the case of Austria and Haider, an obvious and critically important historical parallel did not surface in the leaders' deliberations much: the Kurt Waldheim affair. While running for the Austrian presidency in 1986, Waldheim, a former UN Secretary General (1972-81), was exposed as having lied about his role in the German army during WWII, particularly his possible involvement in brutal actions against civilians. At that time, the international community reacted strongly, much like it did in 1999. Formal protests against his candidacy were made, including threats to cut diplomatic contacts with Austria if Waldheim were elected. The diplomatic offensive did not deter Austrian voters: Waldheim got in with 54 per cent of the vote. For six years Waldheim remained persona non grata in most countries and Austria was partially isolated. There is no evidence that the failure of diplomatic threats and sanctions in influencing the political developments in Austria during the Waldheim episode was ever considered during the informal deliberations that produced the sanctions of the 14 .

\section{IMPACT: enabling joint action}

The impact of the remembered past on the behaviour of the European leaders in this case was mixed. The predominance of the Hitler analogy constrained their cognitive orientation on the situation facing them. Particularly, it crowded out other historical parallels and evidence that might have helped them gain a better understanding of the potential drawbacks of the sanctions they proposed to undertake. Politically and psychologically, the Hitler analogy played into the hands of the hardliners among the European leaders. It enabled them to cast the issue in a compelling moral frame. With the problem represented as the rise of evil in our midst, a tough response became inevitable. Consequently, leaders with doubts about the desirability or feasibility of sanctions were less likely to say so. It also crowded out the formal objection that the EU is not supposed to interfere in the domestic 
politics of its member states, particularly in a case such as this where no actual violations of human rights had actually occurred.

\section{‘THEY’VE DONE IT AGAIN’: SUBMARINE HUNTING IN SWEDEN}

\section{The crisis: challenge, response, and outcome}

During the Cold War period a principal security concern to Sweden was the possible, and suspected, intrusion of Soviet submarines into Swedish territorial waters. During the early 1980s there were at least three well-publicized and politically charged incidents relating to this threat. In September 1980, Swedish navy picked up signs indicating the presence of submarines, and started a hunt during which it deployed a large number of explosives to force the subs to surface, without success (Bynander 2003, Ch. 5.1; SOU 2001, p. $85,49 \mathrm{ff}$.). In October 1981, a stranded Soviet submarine was discovered in the Swedish inner archipelago, outside of Karlskrona (Stern and Sundelius 1992). This triggered tense exchanges and bargaining between the nations about inspection rights and return of the vessel and these ensued for several days. These two incidents provided the backdrop for the third major submarine crisis, the so-called Hårsfjärden incident between September 30 and the end of October 1982. This was again a major, if fruitless, submarine chase, occurring in a blaze of publicity and political aggravation. The 1982 case, presented here, would establish a disturbing pattern for Swedish territorial defence that lasted for the rest of the decade. It provoked political controversy that continues to this day in Sweden.

The Hårsfjärden hunt was preceded by operation Notvarp ('the seining operation'), a secret military exercise to test the capabilities and requirements for effectively detecting and surfacing a submarine. It was the first operation of its kind, and it took place during a major American naval visit to Sweden as well as large-scale NATO exercises in the Baltic. Information about the seining operation, as disclosed in 1987, was no doubt important in setting the stage for the handling of the 1982 crisis (SOU 2001, pp. 85, 356; Larsson 1987). With the 1981 crisis successfully handled and having simulated a major submarine 'catch' just days before the Hårsfjärden episode unfolded, the Swedish military and political leadership were quite confident. This was not to be. Nothing came to the surface, despite major efforts. Eventually, the authorities had to admit that the elusive submarine had in fact never been identified positively, and/or could have managed to slip away. Because of this, Swedish policy-makers suffered a major embarrassment.

The Chief of Staff of the armed forces at the time, Admiral Stefenson, recalled later that 'we thought it was like in Karlskrona, but it was the direct opposite' (Bynander 1998b, p. 67). This suggests that the 1981 crisis formed a pivotal point of reference for the decision-makers in the Hårsfjärden case. On the military side, largely the same people dealt with both crises. In the political arena, the 1982 episode occurred in the vacuum of a government turnover. When information was reported that a foreign submarine was 
trapped in Hårsfjärden, the policy-makers quickly agreed what was going on and how it should be handled. Military and political leaders both assumed that the information was accurate and determined that the intruder should and could be caught. During a retrospective symposium of the main actors held in 2002, erstwhile Minister of Foreign Affairs, Bodström, recalled, 'there was no doubt the government believed there were submarines in Hårsfjärden. It was also reported that the exits of the bay had been closed to the extent that a submarine could not slip out' (Bynander 2002, p. 57, authors' translation).

The two goals Swedish policy-makers were following initially during the 1982 crisis were to detain the submarine and then to gain hard evidence of what it was doing in Swedish territorial waters (Bynander 1998b, p. 68). A contingency plan was made for the military to play for time after surfacing the submarine, providing the government with time to issue a detainment order that in fact had been prepared well in advance. Both these goals were rooted in experience. Since in 1981 the submarine had stranded and catching it was not an issue, the Supreme Commander had decided almost immediately that it should be detained rather than assisted. This sparkled of a brinkmanship crisis of sorts between the Swedish and the Soviet Governments. Sweden had done well out of it since it could claim the moral high ground. There seemed to be no reason to doubt that this part of the scenario was worth repeating, yet it was preferred that the decision to do so was seen to be taken by accountable politicians rather than admirals. Public information policies had been an essential part of the 1981 operation. When Hårsfjärden took place a year later, with the Cold War climate colder rather than warmer, Swedish policy-makers were adamant that the public relations machinery had to do better than during the last real submarine chase (in 1980), when information policy had been incoherent. In 1980, the navy, the defence staff and the ministries had all supplied their own accounts of the events. In 1981, the lessons of that failure had been learned: information policy was centralized, partly to maximize the propaganda value of the crisis. This had been quite successful, and it was this model that the policy-makers replicated in 1982. In fact, the defence staff information office had been scouting significant portions of the Swedish coastline for suitable press centre sites in case other submarine hunts would occur (Bynander (ed.) 2002, p. 106).

\section{Analogical reasoning in the Hårsfjärden case}

The 1981 analogy was readily available in 1982, particularly among the military leaders. It proved to be irresistible yet misleading: because of the hold it exerted on them, key military and political leaders misdiagnosed the situation they were facing. In 1981, with a stranded Soviet submarine on shore, the defence staff had faced a clear and concrete challenge. The Hårsfjärden situation, in contrast, was both ambiguous and complex. First of all, there was no certainty that the signals that had been detected had 
actually been caused by a submarine, let alone a Soviet one. Secondly, the decision-makers underestimated the potential complications involved. Assuming there was indeed a Soviet submarine hiding out in the bay, a major question was which methods should be used to catch it. The key issue was whether or not to run the risk of sinking the submarine (thus killing Soviet navy personnel) by the use of depth charges and the more powerful mine barrages. The rules of engagement developed for this contingency had been sharpened recently. They had never been applied before. By relying on the 1981 analogy, decision-makers sidestepped this problem. They took catching and surfacing for granted and focused their attention on bargaining with the Soviets and on achieving a propaganda victory. The lesson from asymmetrical crises (as the 1981 case had been) was the need for the smaller state to gain a moral advantage in the bargaining process by getting the world on its side. In 1981 extensive Western press coverage along the lines of a David-Goliath scenario had forced the Soviets to assess their steps carefully.

The strong reliance on the 1981 scenario bred overconfidence, particularly among the military leadership. In terms of diagnosis, Swedish Navy leaders simply assumed the submarine could be caught and forced to the surface. In reality, neither was easy, put mildly. In terms of evaluating the appropriateness of policy options, the 1981 analogy led policy-makers to believe that it was neither necessary nor moral to sink the submarine. Yet in reality major firepower would be needed to surface a reluctant submarine, with considerable risk of harm to vessel and crew. This would drastically alter the moral equation, and thus undermine the essence of the Swedish policy.

Ironically, just as in the sanctions case presented earlier, there had been prior incidents that might have given the actors a more appropriate picture of the situation than the 1981 analogy did. The 1980 submarine chase stood out among these. It too had occurred fairly recently, and its morphology was much more similar to the current crisis than the 1981 situation was. The 1980 chase had been an eye opener for the Swedish political leadership and, to a certain extent, to the military leaders as well. In 1980, foreign submarines had remained on Swedish territory long after they had been spotted. This seemingly reckless behaviour of the intruders, assessed to be Soviet submarines, had confused the military leadership. The failure to catch the persistent intruders has solicited strong criticism from leading politicians, but it also bred rumours that the Supreme Commander had let the submarine slip away deliberately, upon orders from the Cabinet (Bynander 1998, p. 379). Supreme Commander Ljung stated it as follows in his diary at the time: 'The political involvement in these matters is to a certain extent annoying. I hardly think the Minister of Defence has considered the consequences of discovering a Soviet submarine that has been successfully neutralised in Swedish territorial waters' (Diary of Lennart Ljung, quoted in Bynander 1998, p. 372). This possible outcome was not considered at all in the Hårsfjärden case. More generally, the more recent and dramatic proportions of the events 
in 1981 appear to have diminished the relative availability and vividness of the 1980 submarine hunting episode, which - in retrospect - might have been the more relevant and representative source of analogical reasoning.

\section{MECHANISM 1: mode of remembrance: ad hoc and institutionalized}

In the Hårsfjärden case the mode of remembrance differed according to the level of action. At the operational level of military contingency planning, the experiences of the 1980 and 1981 incidents had been codified in reports and debriefings, and had led to organizational and policy changes. Organizationally, the 1980 episode triggered the formation of a permanent analysis unit consisting of naval experts. This unit became a crucial part of the navy's readiness. The unit embodied an attempt to develop both an ongoing and 'quick response' intelligence capacity; it played an important role in all the submarine incidents that were to follow (Bynander 1998b, p. 2) Finally, personal and shared experiences of submarine hunting in 1980 and interacting with the Soviets in 1981 also filtered through in terms of the post-1981 scenarios used for submarine defence training, such as the Notvarp exercises.

At the strategic level, evaluations of the political handling of the 1980 and 1981 incidents had occurred, but these evaluations had been condensed into reports and lessons only to a limited extent. The choice of action by the Government in the U137 case (to consider immunity of U137 to be forfeited) had caused a heated debate among experts in international law, both within the country and abroad in the field of international law. The question was whether or not the Government had been too lenient or too tough on the stranded submarine (Theutenberg 1986). It became clear that all intrusions (that is, not accidental groundings) by foreign navy ships in Swedish territorial waters should be treated as hostile acts, in these cases immunity was not pertinent. Opinions on this matter shifted but in 1982 the new government had no intention of being soft on any intruders (Theutenberg 1986, pp. 475-80).

Above all, the previous incidents had been evoked in an ad-hoc fashion and fulfilled primarily cognitive function for the new political leadership. Prime Minister Palme stated at a press conference, 'it is possible for the Swedish Government to order the Navy to sink an intruding ship in Swedish waters' (Theutenberg 1986, p. 470). The former permanent secretary at the Ministry of Defence, Sven Hirdman, explained the broad consensus that existed on the detainment issue if a submarine was surfaced. Detainment was necessary because an intruding submarine '... should not just be rejected from Swedish territory but, in parallel with what happened at Gåsefjärden [i.e., in 1981, auth.], an investigation should be made as to how it got there' (Bynander 1998, p. 381). The hardened political attitude was a result of tougher rules of engagement that did not grant a caught stranded submarine immunity as they had done in the U137 case. The Notvarp 'seining operation' also reinforced the belief that a submarine could be caught, something which was presented to the government as a firm conviction that the exits of Hårsfjärden Bay could indeed be completely sealed off. 


\section{MECHANISM 2: mode of utilization: reaching for repertoires}

When it comes to the mode of utilization, the 1981 crisis analogy was a major factor in defining the 1982 situation as well as in portraying it to the media and the public. At the cognitive level it steered the decision-makers away from the problems of surfacing a submarine. Instead it focused them on acquiring a bargaining position in case Sweden had a Soviet submarine 'in hand'. The fact that both the 1980 and 1981 intruders had been identified as Soviet caused decision-makers to rely even more on the emerging post-1981 SOP's of 'handling' Soviet intrusions. First and foremost, therefore, the 1981 analogy provided the decision-makers with policy prescriptions: the detainment decision (in 1981 the stranded submarine had been detained immediately), the military build-up around Hårsfjärden, and the proactive management of press conferences. Since managing the situation on the ground was left largely to the defence establishment there was little evidence of a search for alternative options by the political leadership.

Military leaders, Ljung and Stefenson in particular, as well as leading politicians, the future Prime Minister Carl Bildt among them, not only experienced the problem as yet another showdown with the Soviets in which Sweden had to act strongly, they also presented it in these terms to the Swedish public. Yet the analogy as such was hardly used primarily to muster needed political support. The public and the media were already on board and deeply engaged in following the actions of the navy.

\section{IMPACT: constraining actors into repetition}

Clearly, the impact of the remembered past in the Hårsfjärden case was one of closing the minds of the decision-makers rather than opening them. It provided a dominant and appealing scenario: repeating the moral victory over the Soviets in 1981. In obscuring other parts of the past (prior futile submarine chases), it prevented the policy-makers from considering alternative scenarios. This belief was also reinforced by the secret military exercise in which a submarine was caught and surfaced just days before the incident. The preoccupation with detaining the submarine is a case in point. Simply scaring it off was not considered an option, even though that would have been much less fraught with operational and political risks. The military action repertoires were fixed, there was no alternative strategy to surfacing the submarine and providing public evidence that Soviet intrusions were still going on. The 1981 analogy also made policy-makers overlook the possibility that surfacing a submarine could imply making casualties. This would have made for a totally different scenario, especially with the press on massive alert. The dilemmas such a scenario entailed were never worked through, simply because they did not carry any weight among the people in charge at the time. 


\section{TOWARDS A THEORY OF HISTORICAL ANALOGIES IN CRISIS MANAGEMENT}

Parts of the remembered past may constitute a siren song for policy-makers, particularly though not exclusively in times of crisis. The allure of particular historical analogies may be irresistible, and condemn policy-makers to various forms of 'fighting a former war' instead of diagnosing and responding to current events on their own terms.

The analysis presented here reiterates this familiar observation, but also qualifies and broadens it. The two case studies show indeed how powerful historical analogies can be, but also lend themselves to a more differentiated account on how they impact the policy-making process. First of all, historical analogies may work as 'filters', that is, providing a readily available 'script' that decision-makers evoke to interpret reality. In both instances, decision-makers regarded the events primarily as 'another case of'. We have seen that this had both enabling and constraining effects. On the enabling side, the more widely shared a particular historical analogy is, the easier it becomes for policy-makers to reach consensus about the definition of the situation at hand.

Moreover, the analogies in these cases can also be thought of as 'teachers'. They did not just help decision-makers to define their situations; they also provided clear policy guidelines on how (not) to act. In the Haider case, the lesson was: don't let a potential dictator come to power; in the submarine case, it was: take control of the submarine and use this to embarrass the Soviets. Moreover, in the latter case, key components of the analogies were even institutionalized at the implementation level, that is, scripted into standard operating procedures. Thirdly, on the constraining side and in line with other research (May 1973; Khong 1992), the case studies suggest that the filtering power of historical analogies can be so strong that they become 'prisons'. Particularly in the context of critical (threatening, volatile, urgent) episodes, the reduction of uncertainty provided by diagnosing the situation in terms of a seemingly perfect historical parallel can be too successful. It freezes efforts to make sense of the situation into rigid adherence to a particular, yet untested, cognitive schema (cf. Staw, Sandelands and Dutton 1981). In the sanctions case, for example, some commentators made harsh judgements about the tunnel vision the European leaders had assumed by playing up the parallels to Hitler's Germany. The Frankfurter Allgemeine editorial (29 January 2000) charged that the government leaders were caught up in a 'Haider hysteria' (see also Sommer 2000).

Fourthly, we may infer from these examples that when particular analogies come to monopolize the discourse of policy-makers on current policy issues this turns other possible analogies into 'blind spots' or 'silences' (see also Trouillot 1995). Indeed, we have seen that in both cases one particular memory was so dominant at the crucial early stages of the critical episode that it caused other potentially relevant parts of the past to be forgotten or at 
least left unused as an aid to contemporary sense-making. In the sanctions case we have the Waldheim analogy; in the Swedish case we have the 1980 Utö submarine hunt.

Fifthly, both cases demonstrate that images of the past do fulfil the rhetorical and justificatory functions attributed to them in the literature. Unlike what has been suggested by authors such as Khong (1992), it is not an eitheror question: cognitive and political functions of historical analogies may go hand in hand. In the sanctions case, some leaders were captivated by the Hitler analogy not just cognitively but also emotionally. At the same time, and partly because of it, they 'used' the analogy to persuade or put pressure on others to join the action against Haider. In the Hårsfjärden case, the 1981 analogy fulfilled primarily a cognitive function. It convinced political and military leaders about the nature of the challenge and suggested the policies to meet it. Yet to some extent it was also used as a weapon to strike at the Soviets - presumably the culprits of the repeated intrusions. Ironically, the Hårsfjärden incident itself later became an analogy, and as such served as ammunition in heated politico-military controversies about Swedish naval defence policy that continue even today (SOU 2001, p. 85; Bynander 2002).

Table 1 organizes these various observations on the forms and functions that historical analogies may take in policy-making and crisis management. In the figure we present six types of analogies, and characterize them in terms of the three dimensions initially presented in figure 1 , above. It is not a formal typology, since some of the analogies differ from others only in degree (prison, trauma) and not in kind.

The analysis presented in this paper has tried to enhance our understanding of how historical analogies work. The cases we have taken are cases where one particular analogy dominates a good part of the decision-making process. In other cases, such as the Iran hostage crisis, there is instead a 'barrage of historical analogies' vying for salience in the minds of decisionmakers (Houghton 2001, p. 17). This leads to the question of why some issues and crises are fully framed in terms of historical analogies and others much less so. In addition one might ask why in any given case, some historical analogies come to the fore and others not.

The answers to these questions must be sought partly in the characteristics of the analogies themselves, partly among those of the decision-makers in question. Houghton suggests that analogies that are readily available (for example, because they refer to very recent and vivid events - even when these are highly infrequent and unlikely to recur) and seemingly representative (that is, morphologically 'fitting' the present situation - even when this ignores maxims of statistical probability) to the issue at hand are most likely to carry weight in the decision-making process. The vividness and emotional power of any sort of analogy that referred to the Nazi era was coincidentally revived by the Stockholm Holocaust conference which all of the key players were attending at the time the issue arose. Finally, the Waldheim analogy was indeed more proximate than the Hitler analogy, but 
TABLE 1 Historical analogies in crisis management: mechanisms and impact

\begin{tabular}{|c|c|c|}
\hline $\begin{array}{l}\text { Analogy } \\
\text { characterizations }\end{array}$ & Mechanisms and impact & Indicators \\
\hline 1. Filter & $\begin{array}{l}\text { Mechanisms: spontaneous; } \\
\text { cognitive } \\
\text { Impact: enabling, i.e. providing an } \\
\text { historical 'schema' or 'script' that } \\
\text { helps decision-makers }\end{array}$ & $\begin{array}{l}\text { Elaboration of particular historical } \\
\text { references in cause-effect utterances } \\
\text { by policy-makers in the deliberation } \\
\text { process }\end{array}$ \\
\hline 2. Teacher & $\begin{array}{l}\text { Mechanisms: deliberate; cognitive } \\
\text { or political (depending on arenas } \\
\text { and audiences) } \\
\text { Impact: enabling, i.e. providing } \\
\text { policy guidelines }\end{array}$ & $\begin{array}{l}\text { Elaboration of particular historical } \\
\text { references in goals-means statements } \\
\text { by policy-makers in the deliberation } \\
\text { process and/or in SOP's }\end{array}$ \\
\hline 3. Prison & $\begin{array}{l}\text { Mechanisms: spontaneous; } \\
\text { cognitive and political } \\
\text { Impact: constraining, i.e. a } \\
\text { quasi-monopolistic frame that } \\
\text { prematurely narrows sense- } \\
\text { making and political space }\end{array}$ & $\begin{array}{l}\text { Disproportionately frequent and/or } \\
\text { highly expansive (i.e. overgeneralized, } \\
\text { overstretched) reference of } \\
\text { types } 1 \text { and } 2\end{array}$ \\
\hline 4. Blind spot & $\begin{array}{l}\text { Mechanisms: spontaneous or } \\
\text { deliberate; cognitive } \\
\text { Impact: constraining: i.e. } \\
\text { 'forgotten' analogies, } \\
\text { overlooked by } \\
\text { policy-makers }\end{array}$ & $\begin{array}{l}\text { Conspicuous absence in policy-makers' } \\
\text { deliberations and texts (this presumes } \\
\text { the analyst 'knows' about possible } \\
\text { alternative analogies) }\end{array}$ \\
\hline 5. Weapon & $\begin{array}{l}\text { Mechanisms: deliberate; political } \\
\text { Impact: enabling, i.e. tool for } \\
\text { political persuasion, pressure } \\
\text { and justification that actors may } \\
\text { employ when dealing with } \\
\text { others }\end{array}$ & $\begin{array}{l}\text { Strategically invoked with susceptible } \\
\text { audiences and avoided in other fora } \\
\text { (or presented to other audiences } \\
\text { when sanctioned) }\end{array}$ \\
\hline 6. Trauma & $\begin{array}{l}\text { Mechanisms: spontaneous; } \\
\text { cognitive/emotional } \\
\text { Impact: constraining, i.e. } \\
\text { references to extremely } \\
\text { aggravating past episodes that } \\
\text { constitute 'raw nerves' in } \\
\text { collective memory; may well } \\
\text { overshadow other } \\
\text { considerations }\end{array}$ & $\begin{array}{l}\text { Widespread use of highly emotional } \\
\text { language and symbolic acts. Strong } \\
\text { preoccupation with worst-case } \\
\text { scenarios and moral issues }\end{array}$ \\
\hline
\end{tabular}

bear in mind that the Waldheim affair occurred before any of the late-1999 European leaders had been in office. So personal experience (in this case of using sanctions to deal with unwanted Austrian political leaders), the other factor singled out by Houghton as a crucial predictor of an analogy's potential power, could not compensate for the much greater vividness of the Hitler analogy in this case. In the Hårsfjärden case, on the contrary, many decision-makers had personal experience of both the 1980 and 1981 submarine hunts, yet the former was ignored and the latter overemphasized. 
Perhaps this was because the latter was more recent and more vivid (it became a real crisis; the 1980 hunt ended in nothing). But it may also have been more psychologically 'appealing' in that it referred to an episode that had been classified as a clear tactical victory of the Swedish David over the Soviet Goliath. Maybe decision-makers are more likely to evoke both the very pleasant (former victories) and the very unpleasant (defeats, traumas), and thereby ignore the murkier realities of 'muddling through'.

These speculations on the causes of the relative power of historical analogies are quite insufficient to resolve the issues raised here. Houghton's approach, to rely on the well-known cognitive heuristics of availability and representativeness to explain the currency of analogies, is not sufficiently precise. These two mechanisms both refer to what might be called the 'evocation' of an analogy in a particular situation but in and of themselves they do not explain why this happens. What can be done at present is to take the various factors as alternative hypotheses, currently with mixed support from a small and possibly skewed sample of cases, which are to be tested in further research:

1. The more recent the events to which a historical analogy refers, the higher the likelihood that this analogy will be evoked in contemporary policy making;

2. The more characteristics of a historical analogy resemble the features of a contemporary situation, the more likely its use;

3. The higher the proportion of policy-makers that have personal experience of the events referred to in a particular historical analogy, the more likely its use;

4. The greater the individual and mass psychological impact of the events referred to in a particular historical analogy, the more likely its use;

5. The more a particular historical analogy fits the standard operating procedures and/or organizational interests of the entity that a policy-maker belongs to, the more likely its use by that policy-maker.

Good governance should rest on carefully considered connections between past, present and future. Our cases show that productive learning from history does not come easily. It requires a careful calibration of the organization of collective memory, the composition of decision-making bodies, and the flow of analysis and advice from the bureaucracy to the political leaders. In the area of historical analogies it would seem pertinent therefore to conduct more elaborate comparative studies to establish the relative frequency of the various forms of analogical reasoning and the explanatory power of the various hypotheses discussed above.

\section{ACKNOWLEDGEMENT}

Thanks to Arjen Boin, Johan Eriksson, Eric Stern for comments. Thanks to Sara Larsson and Jenny Lundgren for their permission to draw heavily on their analysis of the Austrian case. 


\section{REFERENCES}

Baldwin, D. 1985. Economic Statecraft. Princeton, NJ: Princeton University Press.

Bennett, A. 1999. Condemned to Repetition? The Rise, Fall and Reprise of Soviet-Russian Military Interventionism, 1973-1996. Cambridge, MA: MIT Press.

Berger, W.A. 2001. 'Der Fall Berlusconi', Die Zeit, 20, 7.

Blight, J. 1990. The Shattered Crystal Ball: Fear and Learning in the Cuban Missile Crisis. Lanham, MD: Rowman and Littlefield.

Bobrow, D. 1989. Stories remembered and forgotten, Journal of Conflict Resolution, 33, 187-209.

Bovens, M. and P. 't Hart. 1996. Understanding Policy Fiascoes, New Brunswick, NJ: Transaction.

Breslauer, G.W. and P.E. Tetlock (eds). 1991. Learning in US and Soviet Foreign Policy. Boulder, CO: Westview Press.

Butler, T. (ed.). 1989. Memory: History, Culture and the Mind. Oxford: Blackwell.

Bynander, F. 1998a. Crisis Analogies: A Decision-making Analysis of the Swedish Submarine Incident of 1982. Stockholm: Swedish Institute of International Affairs, report No. 29.

Bynander, F. 1998b. 'The 1982 Swedish Hårsfjärden Submarine Incident: A Decision-making Analysis', Cooperation and Conflict, 33, 367-407.

Bynander, F. (ed.). 2002. Ubåtsfrågan: Ett symposium. Stockholm: The Swedish National Defence College.

Bynander, F. 2003. The Rise and Fall of the Submarine Threat: Threat Politics and Submarine Intrusions in Sweden 1980-2002. Dissertation. Uppsala: Department of Government, Uppsala University.

Caruth, K. (ed.). 1995. Trauma: Explorations in Memory. Cambridge: Cambridge University Press.

Connerton, P. 1989. How Societies Remember. Cambridge: Cambridge University Press.

Covington, C.R. 1985. 'The Development of Organizational Memory in Presidential Agencies', Administration and Society, 17, 171-96.

Etheredge, L.S. 1985. Can Governments Learn? New York: Pergamon.

Flin, R.K. 1996. Sitting in the Hot Seat. Chichester: John Wiley.

Foote, K.E. 1990. 'To Remember and to Forget: Archives, Memory and Culture', American Archivist, 53, 378-92.

Hacker, J.S. 2001. 'Learning from Defeat? Political Analysis and the Failure of Health Care Reform in the United States', British Journal of Political Science, 31, 61-94.

Hammargren, B. 2000. Konferensen om förintelsen - om egen skuld teg de helst, Svenska Dagbladet, 28 January.

Hemmer, C. 1999. 'Historical Analogies and the Definition of Interests: The Iranian Hostage Crisis and Ronald Reagan's Policy Toward the Hostages in Lebanon', Political Psychology, 20, 2, 267-89.

Houghton, D.P. 2001. U.S. Foreign Policy and the Iran Hostage Crisis. Cambridge: Cambridge University Press.

Hrbek, R. 2003. 'Interview', in S. Larsson and J. Lundgren (ed.), De fjortous sanktioner mot Ōsterrike (The Sanctions Against Austria). Stockholm: Swedish Defence College.

Hybel, A.R. 1990. How Leaders Reason: US Intervention in the Caribbean Basin and Latin America. Oxford: Blackwell.

Isaacson, W. and T. Evan. 1986. The Wise Men: Six Friends and the World they Made. New York: Touchstone.

Khong, Y.F. 1992. Analogies at War, Princeton, NJ: Princeton University Press.

Larsson, C. 1987. 'Den stora ubåtsfällan', Ny Teknik, No. 21.

Larsson, S. and J. Lundgren. 2003. De fjortous sanktioner mot Ōsterrike (The Sanctions Against Austria). Stockholm: The Swedish Defence College/Crismart.

Levitt, B. and J.G. March. 1988. 'Organizational Learning', Annual Review of Sociology, 14, 311-28.

Levy, J. 1994. 'Learning and Foreign Policy: Sweeping a Conceptual Minefield', International Organization, 48, 279-312.

Mannarelli, T, K.H. Roberts and R. Bea. 1996. 'Learning how Organizations Mitigate Risk', Journal of Contingencies and Crisis Management, 4, 83-92.

March, J.G., and J.P. Olsen 1975. 'The Uncertainty of the Past: Organizational Learning under Ambiguity', European Journal of Political Research, 3, 147-71.

Martin, L. 1992. Coercive Cooperation: Explaining Multilateral Economic Sanctions. Princeton, NJ: Princeton University Press.

May, E.R. 1973. 'Lessons' of the Past: The Use and Misuse of History in American Foreign Policy. New York: Oxford University Press.

Middleton, D. and D. Edwards (eds). 1990. Collective Remembering, London: Sage. 
Neustadt, R.E. and E.R. May. 1986. Thinking in Time: The Uses of History in Policy Making. New York: Free Press.

Nora, P. 1989. 'Between memory and history: Les Lieux de Memoire', Representations, 26, 7-25.

Pidgeon, N. 1997. 'The Limits to Safety? Culture, Politics, Learning and Man-made Disasters', Journal of Contingencies and Crisis Management, 5, 1-14.

Pierson, P. 2001. 'Increasing Returns, Path Dependence and the Study of Politics', American Political Science Review, 94, 2, 251-67.

Rose, R. 1993. Lesson-drawing in Public Policy. New York: Chatham House.

Rosenthal, U. and P. 't Hart. 1989. 'The South Moluccan Hostage-takings', in U. Rosenthal, M.T. Charles and P. 't Hart (eds), Coping with Crises: The Management of Disasters, Riots and Terrorism, Springfield, IL: Charles Thomas.

Sabatier, P. and H. Jenkins-Smith. (eds). 1993. Policy Change and Learning: The Advocacy Coalition Approach, Boulder, CO: Westview Press.

Sagan, S. 1993. The Limits of Safety: Organizations, Accidents, and Nuclear Weapons. Princeton, NJ: Princeton University Press.

Schudson, M. 1992. Watergate in American Memory: How we Remember, Forget, and Reconstruct the Past. New York: Basic Books.

Shimko, K. 1995. 'Foreign Policy Metaphors: Falling "Dominoes" and “Drug Wars"', in L. Neack, L., J. Hey and P. Haney (eds), Foreign Policy Analysis: Continuity and Change in Its Second Generation. Englewood Cliffs, NJ: Prentice Hall.

Smith, P. 2001. 'Memory without History: Who owns Guatemala's past?', The Washington Quarterly, $24,59-72$.

Snow, D.A. and R.D. Benford. 1992. 'Master Frames and Cycles of Protest', in A.D. Morris and C. McClurg

Mueller (eds), Frontiers in Social Movement Theory. New Haven, CT: Yale University Press, pp.133-55.

Sommer, T. 2000. 'Contra-Bann über Österreich', Die Zeit, 7, 15.

Sorokin, P. 1942. Man and Society in Calamity. New York: E.P. Dutton.

SOU. 2001. Perspektiv på ubåtsfrågan. Statens offentliga utredningar, Vol. 85. Stockholm: Fritzes.

Staw, B., L. Sandelands and J. Dutton. 1981. 'Threat-rigidity Effects in Organisational Behavior', Administrative Science Quarterly, 26, 501-24.

Stern, E. 1997. 'Crisis and Learning: A Conceptual Balance Sheet', Journal of Contingencies and Crisis Management, 5, 69-86.

Stern, E. and B. Sundelius. 1992. 'Managing Asymmetrical Crisis: Sweden, the USSR, and U137', International Studies Quarterly, 36, 213-39.

Stern, E. and B. Sundelius. 2002. 'Crisis Management Europe: an Integrated Regional Research and Training Program', International Studies Perspectives, 3, 71-88.

Stone, D. 1997. Policy Paradox: The Art of Political Decision-making, New York: Norton.

Sturken, M. 1997. Tangled Memories: The Vietnam War, the AIDs Epidemic and the Politics of Remembering. Berkeley, CA: University of California Press.

Tetlock, P. and R.N. Lebow. 2001. 'Poking Counterfactual Holes in Covering Laws: Cognitive Styles and Historical Reasoning', American Political Science Review, 95, 4, 829-44.

Theutenberg, B. J. 1986. Folkrätt och säkerhetspolitik (International law and National society). Stockholm: Norstedts Förlag AB.

Trouillot, M.-R. 1995. Silencing the Past: Power and the Production of History, Boston, MA: Beacon Press.

TT (Swedish News Agency). 2000. Sverige stödjer uttalande. Brussels: TT, 31 January.

Vaughan, D. 1996. The Challenger Launch Decision, Chicago, IL: University of Chicago Press.

Date received 11 September 2002. Date accepted 7 July 2003. 